\title{
A Socio-Legal Investigation into the Perception of Dying and Death among Adults in EBO Community, Southern Nigeria
}

\section{Barr Emmanuel Imuetinyan Obarisiagbon}

Dept. of Sociology \& Anthropology, University of Benin, Benin City eiobarisiagbon@yahoo.com and emmanuel.obarisiagbon@uniben.edu

\author{
Doi:10.5901/jesr.2015.v5n3p255
}

\begin{abstract}
This study was initiated to socio-legally investigate the perception of dying and death amongst adults in Ebo Community in Southern, Nigeria. In most traditional communities, it would appear that the perception of people about death is wrapped up in their fear of the inevitable occurrence. Little wonder that discussions and preparations are not made towards it. The study which is both exploratory and qualitative employed a cross-sectional design. A combination of quantitative and qualitative techniques was utilized to collect data from the respondents. A total of 100 respondents were quantitatively sampled while 20 in-depth interviews were also conducted. A descriptive analysis of the quantitative data collected was undertaken using frequency distribution while the manual content analysis was used for qualitative data collected from the field work. Findings from this investigation showed that almost all deaths in Ebo Community in Southern Nigeria were attributed to witchcraft and that the people see death as a frightening and scaring phenomenon that should neither be talked about nor legally prepared for. Based on the findings of the study, recommendations were made that the media, church and other credible agents of socialization should engage in enlightenment campaign programmes to create awareness that dying and death are not caused by witchcraft and besides, people should feel free to discuss and prepare legally for this natural inevitability.
\end{abstract}

Keywords: Death, Dying, Wills and Witchcraft.

\section{Introduction}

Whether we accept it openly or not, most humans fear death. There appears to be an awe and mystery surrounding its existence even though it is one great certainty in life. Death remains a tragedy that strikes families throughout the world on a daily basis, yet the response it elicits is shaped by the attitudes that are prevalent in a given culture (Abanyan, 2012). Death as the end of life has always been a central concern of law. Many legal issues related to death include laws that determine whether death has actually taken place as well as when and how it took place and whether or not another person should be charged to court for having caused it. These indeed are global issues that needs to be addressed.

The question is why are people frightened and scared of dying and so much relegation of death to the periphery of our lives as if it can be kept out of sight and out of mind. This study seeks to understand these issues as well as provide necessary information about how to prepare in advance for death.

\section{Statement of Problem}

Without doubt, the issue of death and dying remain central to all humans even though people live in denial of it or are afraid to talk about it. In traditional Nigeria communities, most deaths are attributed to witchcraft despite the plethora of evidence to the contrary. According to WHO (2011), the leading cause of death in Africa is HIV (AIDS, 19\%) followed by acute respiratory diseases like flu or bronchitis and diarrhea. Although, the occurrence of death and the process of dying is the most certain thing the world over, it would however appear that people are the least prepared for it as they are scared and frightened to even talk about it instead, euphemistic languages like: "passed on", "gone to meet the maker", "kicked the bucket" and so are used to describe death. The question is, why do people not prepare towards their own death and what is responsible for so much fear and denial of death among people in traditional societies. These are some issues that this study seeks to unravel. 


\section{Objectives of Study}

This study is designed to:

a. Ascertain the main cause of death in Ebo Community from the perception of Community members

b. Investigate the perception of adults in Ebo Community, Southern Nigeria towards death and dying

c. Evaluate the legal preparation towards death

\section{Review of Related Literature}

It must be stated from the outset that even though the subject matter, death and dying is one that most people avoid discussing. As aptly put by Olaitan (2003) and Giddens (1990) death remains a reality that relatively few people want to face or talk about. The issue goes un discussed as people are afraid of dying. It is nonetheless central to religion and philosophy and science as they have wrestled with it since the beginning of human history.

The concept of death and dying means different things to different people, different societies and different religions. In general conception, death simply means the end of life while dying is the process of approaching death including the choices and actions involved in the process. The difference between death and dying is that in dying, the individual goes through a process of gradual termination before death occurs. In death, this process is absent or is relatively short. In both instances, the relatives are left behind to go through the grieving process (Eyetsemitan, 2002).

Mbiti (1980) sees death as that phenomenon which stands between the world of human beings and the world of the spirits, between the visible and the invisible. Veatch (1997) on his part opines that "death is a complete change" in the status of a living entity characterized by the irreversible loss of those characteristics that are essentially significant to it.

\section{Legal Perception of Death}

Death has always been a central concern of law. The law recognizes different forms of death, not all of them meaning the end of physical life. Legal death is a presumption by law that a person has died. It arises following a prolonged absence, generally for a prescribed number of years (in Nigeria, seven years) during which no one sees or hears from the person and there is no reason for the person's disappearance that would be incompatible with a finding that the individual is dead (Evidence Act LFN, 2004).

Besides the above, there are several legal issues related to death which includes law that determines whether a death has actually occurred, as well as when and how it occurred and whether or not another individual will be charged for having caused it.

In the eyes of the law, death is not a continuing event but something which takes place at a precise moment in time. The Nigerian courts will not wield authority concerning a death. The determination of whether an individual has died and the way in which this is proved by the per son's vital signs is not a legal decision but rather a medical judgment. The option of qualified medical personnel will be taken into consideration by judges when a controversy exists as to whether an individual is still alive or has died.

Eyetsemitan (2002) has rightly observed that the preparation for death could be either formal or informal. He further noted that in societies where there is a strong entrenchment of the rule of law, the legal dimension to death is very vital. Some of the formal ways people prepare for death include buying a life insurance policy, drafting a Will or having a Living Will.

A Legal Will allows a person to state how his estate is to be dispersed upon death. However, in Nigeria, the Wills Act (1837) was operational. However, various States of the Federation of Nigeria have at different times enacted their own Wills Laws. For instance in Edo State, the Wills Laws of the former Bendel State Edict 1976 now applicable to Edo State, Southern Nigeria is operational. It is instructive to add here that Section 3 (1) of the said Edict implies that when a Will is being prepared, it must take cognizance of the custom of the people. This explains as Obarisiagbon and Akhigbe (2010) puts it, the doctrine of "igiogbe" among the Bini people. This doctrine was given judicial interpretation in the case of Agidigbi V Agidigbi (1996)5 NWLR Pt 13, P 272 where the court held that the house where the deceased lived, died and was buried belongs absolutely to his eldest surviving son and the law will frown seriously at the contrary.

The Living Will is yet another formal legal document which allows a person to give specific directives to terminate his life should "extra-ordinary" means be taken to extend it. It has been argued that a person with a durable power of attorney can make decisions on behalf of another person as to life. (Eyetsemitan 2002) 
Eyetsemitan (2002) has noted that these legal measures taken in preparation for death hold sway in advanced nations due largely to their high level of adherence to the rule of law and the need to protect their individualist values even in the grave. Conversely, Obarisiagbon and Akhigbe (2010) have also been observed that in Nigeria, many individuals are however not keen in making a Will because, it reminds them of death. This formal preparation for death only occurs when they go through the dying process. The dying process, unlike sudden death allows for time to take care of unfinished businesses.

Beside the legal perception of death, it is interesting to know that the other aspect of the definition of death that has become of interest to scholars is the social perception. Kaistenbaum (1975) has observed that death can be looked at socially. He noted that people are socially dead when they are treated as unthinking and unfeeling objects. Interestingly, this view re-echoed in the famous dictum of a renowned French philosopher, Rene Descartes who asserted that he exists only when he is thinking ("cogito ergo sun"- I think therefore I am) (Russell, 1979). As Abanyan, (2012) has noted, social death occurs when people talk about a dying person rather than to a dying person even when the dying person is capable of hearing and understanding what is being said. In sum, social death occurs before physical death.

Generally in Nigeria, the attitude of the people towards death is enveloped in their firm belief in witchcraft. There is an assumption that nobody dies a natural death in Africa. If someone dies, it is assumed that the person was only hated and afflicted by evil men through a combined accord of the kin groups. As rightly noted by Abanyan, (2012) the victim's relatives look to supernatural powers in seeking for causes. There are allegations and counter-accusations against the family members with the wife as the prime suspect.

Offiong (1999) on his part observed that almost every illness, death, difficult child birth, poor harvest, sickly livestock and even sterility are caused by witchcraft. Witchcraft theory seems to provide both the individual and society with a scape-goat and the feelings of well-being even if the patient dies there from.

This view is further supported by Nadel (1951) when he stated that mysterious diseases, barrenness or fertility in fact, mortality, irregular menstruation, accident and death are all explained in the idiom and logic of witchcraft. Nadel (1951) view is further given credence to by the works of Despelder and Strickland (1998). They confirm that some traditional societies today, there is a reliance on an ecological orientation in seeking causes of disease and death. They look to the supernatural and investigate the possible role of such phenomena as the wind or moon heredity. This was perhaps why Horton (1967) explained that the sick or afflicted person goes to consult a diviner as to the causes of their problems.

\section{Theoretical Orientation}

This study adopts the Kubler Ross Theory of Death and Dying though different theoretical models exist, Kubler Ross is probably the most familiar. Most times, humans feel uncomfortable talking to and interacting with a person who is dying. This is partly due to the fact that we have no way of understanding their perspective and what they are experiencing mentally, emotionally and spiritually.

However, studying the Kubler Ross theory of death and the dying process can in fact help us become more comfortable by broadening our knowledge and insight into the perspective of the dying person. Elizabeth Kubler Ross (1969) in her famous book on Death and Dying, saw a pattern emerging that she expressed in the way of stages. She stated that there were five stages of dying thus:

i. Denial and Isolation: In this stage, most people temporary are in shock and so respond in denial of the reality.

ii. Anger: This is when the person recognizes that denial of the reality cannot continue.

Psychological responses like "why me? It is not fair" are often heard

iii. This stage involves the beliefs that the person can avoid a cause of grief. Usually, the negotiation for an extended life is made with a higher power in exchange for a reformed life style.

iv. Depression: At this stage, the person becomes saddened by the stark reality of death. Here, he may become silent, refuse visitors and spend more time being mournful and sullen.

v. Acceptance: This is the last stage and usually involves the embracing of mortality or inevitable future.

It is instructive to note here that this theory believes that the other persons who are drawn into a dying person's experiences such as family members and friends may also experience similar stages of adjustment.

Fine as the rendition of the stage theory of death and dying by Kubler Ross might appear, scholars like Bonanno (2004) and Friendman and James (2012) have noted that empirical research has provided no support for this model. Besides, the five sets of psychological reactions that are at the heart of this theory can be criticized as overly broad in their formulation, potentially misleading in at least instance, insufficient to reject the full range of human reactions to 
death and dying and inadequately grounded for the broad ways in which they have been used.

In spite of these criticisms, this theory has brought to the fore, the fact that those who are coping with dying are living human beings who will react in their individual ways to their own unique challenges that confront them and who may have unfinished needs that they want to address (Corr, 1992). Another lesson which Kubler Ross always stressed is that all individuals need to learn from those who are dying and coping with dying in order to come to know themselves better as limited, vulnerable, finite and mortal but also as resilient, adaptable, inter-dependent and worthy of love.

\section{Methodology}

Data for this study was collected through a combination of quantitative and qualitative methods. Fieldwork began with the qualitative aspect of the research which provided important insights for the investigation of the study area. As it is common practice in most studies using triangulation, qualitative data are immensely important and must precede the survey method in order to facilitate the design of the questionnaire.

Qualitative data for the present analysis was elicited through in-depth interview which employed the snowball sampling method while the questionnaire was used for the quantitative method. A hundred and ten (110) questionnaires were administered out of which a hundred and five (105) were returned for analysis. Only a hundred (100) were useful. This however represents a return rate of $90.9 \%$ and is considered significant. Ebo Community was stratified along the existing quarters and with the aid of the random sampling method, the final elements in the population were selected.

The quantitative data was edited and cleaned to eliminate inconsistencies which could undermine the validity of the data. A descriptive analysis of data was undertaken using frequency distribution while the qualitative data was analyzed using a manual content analysis. The procedure began with a transcription and translation of a tape recorder of the IDIs. This was thereafter followed by then the examination and isolation of various responses that were relevant to the study objective.

\section{Results and Discussions}

Table 1: Percentage Distribution Of Respondents By Selected Socio-Demographic Characteristics

\begin{tabular}{|c|c|c|}
\hline Categories & Frequency & Percentage (\%) \\
\hline Male & 75 & $75 \%$ \\
\hline Female & 25 & $25 \%$ \\
\hline $30-39$ & 5 & $5 \%$ \\
\hline $40-49$ & 12 & $12 \%$ \\
\hline $50-59$ & 34 & $34 \%$ \\
\hline $60-69$ & 28 & $28 \%$ \\
\hline 70 and above & 11 & $11 \%$ \\
\hline Total & 100 & $100 \%$ \\
\hline \multicolumn{3}{|l|}{ Marital Status } \\
\hline Single & 3 & $3 \%$ \\
\hline Married & 84 & $84 \%$ \\
\hline Divorced & 7 & $7 \%$ \\
\hline Widowed & 6 & $6 \%$ \\
\hline Total & 100 & $100 \%$ \\
\hline \multicolumn{3}{|l|}{ Religion } \\
\hline Christianity & 88 & $88 \%$ \\
\hline Islam & Nil & $\underline{\underline{0}} \%$ \\
\hline African Traditional Religion & 12 & $12 \%$ \\
\hline Total & 100 & $100 \%$ \\
\hline \multicolumn{3}{|l|}{ Education } \\
\hline No schooling & 14 & $14 \%$ \\
\hline Primary & 26 & $26 \%$ \\
\hline Secondary & 48 & $48 \%$ \\
\hline Tertiary & 12 & $12 \%$ \\
\hline Total & 100 & $100 \%$ \\
\hline Occupation & & \\
\hline
\end{tabular}




\begin{tabular}{|l|c|c|}
\hline Public service & 14 & $14 \%$ \\
\hline Farming & 41 & $41 \%$ \\
\hline Trading & 10 & $10 \%$ \\
\hline Artisans & 30 & $30 \%$ \\
\hline Unemployed & 5 & $5 \%$ \\
\hline Total & 100 & $100 \%$ \\
\hline
\end{tabular}

Source: Field work, December, 2014 - February, 2015

Table 1 displays information on selected demographic variables of respondents. About $75 \%$ of the respondents were males while $25 \%$ were females. This shows that the males in the community were more accessible. About $5 \%$ of the respondents were in the age bracket of $30-39$ years, $12 \%$ were in the age bracket of $40-49$ years, $34 \%$ were in the age bracket of 50-59 years while $28 \%$ and $11 \%$ fell into the age bracket of 60-69 and 70 years and above respectively. Similarly, about $3 \%$ of the respondents were single $84 \%$ were married while $7 \%$ and $6 \%$ were divorced and widowed respectively. This shows that marriage in Ebo Community in Southern Nigeria is highly stable.

As expected, a large majority of the respondents were Christians representing $83 \%$ this is to be expected considering the fact that Ebo Community (Benin) Southern Nigeria had an early contact with the Christian Missionaries and the superb evangelical work of the late Archbishop Benson Idahosa of the Church of God Mission Int'I Inc. 12\%.and $\underline{0} \%$ were Traditionalists and none were Muslims.

Furthermore, $14 \%$ of the respondents had no formal education while $26 \%$ of the respondents had primary education $48 \%$ and $12 \%$ respondents had secondary and tertiary education respectively. As can be gleaned from the above, tertiary education is yet to be fully embraced by the people of Ebo Community in Southern Nigeria due largely to the fact that land speculation fetches a lot of money to both the youths and the elders of the community. As expected, only $14 \%$ of the respondents are engaged in the public service, this is due largely to the fact that majority of the people in the community, outside the migrants are without tertiary education $41 \%$ of the respondent were farmers while $10 \%$ were traders, $30 \%$ and $5 \%$ of the respondents were artisans and unemployed respectively.

Table 2: Relationship Between Witchcraft And Death

\begin{tabular}{|l|c|c|c|}
\hline Question 1. & Response & Frequency & Percent \\
\hline Would you say that witchcraft is a major cause of death of people in Ebo & Yes & 76 & $76 \%$ \\
\cline { 2 - 4 } community, Southern Nigeria? & No & 24 & $24 \%$ \\
\hline
\end{tabular}

Source: Field work December 2014 - February 2015

Table 3: Perception Of People Towards Death And Dying

\begin{tabular}{|l|c|c|c|}
\hline Question 2. & Response & Frequency & Percent \\
\hline \multirow{2}{*}{ Should people discuss death and dying? } & Yes & 38 & $38 \%$ \\
\cline { 2 - 4 } & No & 62 & $62 \%$ \\
\hline
\end{tabular}

Source: Field work December 2014 - February 2015

Table 4: Legal Will And Preparation Towards Death

\begin{tabular}{|l|c|c|c|}
\hline Question 3. & Response & Frequency & Percent \\
\hline \multirow{2}{*}{ Do you agree that wills should be made by people as a way of preparing for their death? } & Yes & 19 & $19 \%$ \\
\cline { 2 - 4 } & No & 81 & $81 \%$ \\
\hline
\end{tabular}

Source: Field work December 2014 - February, 2015.

Table 2 indicates that as high as $76 \%$ of the respondents believe that death is caused by witchcraft and the activities of witches. This view is further given credence to by Offiong (1999) when he observed that almost all kinds of diseases and deaths are caused by withcraft. He noted further that among the Ibibios of Nigeria, almost every disease, death, difficult 
child birth, poor harvest, sickly livestock and even sterility are caused by witchcraft. His view collaborates the opinions of some IDI respondents as clearly captured by one interviewee.

"When my wife died, I went with some of my family elders to consult the oracle and the oracle revealed that an evil woman used her witch to kill my wife over a quarrel they had near the village borehole."

Table 3 indicated that as high as $62 \%$ of the respondents felt that people should not talk nor discuss anything about death. This view is further buttressed by the Olaitan (2003) when he found in his study that death remains a reality that relatively few people face or talk about. He observed that people try to live as if death could not happen to them. Gidden's (1990) work gives credence to this finding and is very apt. From his postulation, death tends to be a subject that goes un-discussed as people are frightened of dying. Infact, rather than having open discussions, people tend to view death as a feared enemy. The above collaborates the view of some IDI respondents as vividly captured by one of the main interviewees.

"Why should I sit down with anybody and be discussing death. We don't talk about death in our place here."

Table 4, shows that as high as $81 \%$ do not believe that Wills should be made by people as a way of preparing for their own death. This finding finds support in the work of Eyetsemitan (2002). To him the legal measures taken in preparation for death are seen in most western societies and not traditional societies like Nigeria. He attributes this to their high level of adherence to the rule of law, and the need to protect their individualistic values even in the grave. Conversely, he argued that for many individuals in traditional societies, these formal preparations remind them of death and they would rather not be reminded of it. Thus, the legal dimension to death in Nigeria is not as developed as in most western societies.

This position is very well collaborated by the views of one IDI respondent when he stated that:

"Will is alien to me and my people. As a chief, my people know how to share my propery when I die; so why should I bother myself preparing a will."

\section{Conclusion and Recommendations}

From the findings of this study, there is little or no doubt about the fact that in Ebo community, Southern Nigeria, the idea of death is wrapped up in their belief in witchcraft. For this reason, they believe that nobody dies a natural death. Besides, it would appear that this belief in witchcraft has also affected their perception of death to the extent that the people are even afraid to talk or discuss the issue of dying let alone death. This obviously explains why they are less prepared for death by way of preparing a Will to avert disputes, conflict and family vendetta upon the demise of the person. Based on the findings of this study, the following recommendations have been made.

1. The media, the church and other credible agents of socialization should engage in the enlightenment of the people with a view to creating a better understanding of the natural concept of dying and death.

2. It is also recommended that people should involve in health policy - NHIS should be fully embraced and since death is an inevitability, people should be encouraged to make "Wills". This is a way of preparing for their death just like they prepare for any other thing (like wedding and graduation ceremonies) in life.

3. We strongly advocate that the Federal and State government should plan to include death and dying education in school curriculum and people should be encouraged to embrace and or take the course.

4. Finally, the Nigerian experience provides a model for understanding dying and death issues in other nonwestern societies that share similar historical, political and cultural experiences.

\section{References}

Abanyam, N.L. (2012) "The Concept of Death and its Implication Among Tiv People of Central Nigeria" Africa Dynamics of Social Science Research Journal, Vol. 2 No. 1. Pp 18-30

Agidigbi V Agidigbi (1996)5 NWLR Pt 13, P 272

Corr, (1992) C.A. "A Task-Based Approach to coping with Dying" Omega: The Journal of Death and Dying 24:81-94.

Despolder, L.A. Strickland, A.L. (1998) The last dance: Encountering death and dying, California: Mayfield Publishing Company.

Evience Act, Laws of the Federation of Nigeria, 2004.

Eyetsemitan, F. (2002) Suggestions regarding the cross - cultural environment as context for human development and aging in non - 
western cultures, psychological reports, Vol. 90 pp 823-833

Giddens, A. (1990) Sociology Cambridge: Polity Press.

Kastenbaum, R. (1975) "Is death a life crisis? A confrontation with death in theory and practice" In N. Datan and L.H. Ginsberg (ed) Life span developmental psychology normative life crisis. New York: Macmillian.

Kubler - Ross, E. (1969) On Death and Dying, New York, Macmillan

Leming, R.R \& Dickinson, G.E (1994) Understanding Dying, Death and Bereavement. Orlando, Florida: Harcourt Brace \& Co.

Mbiti J.S. (1969) African Religions and Philosophy, New York: Praegers Publishers.

Nadel, S. F. (1952) Witchcraft in Four African Societies. An essay in comparison. American Anthropologist, Vol. 54, pp 18-29

Obarisiagbon E.I. and Akhigbe E (2010) The Doctrine of Igiogbe-A Social-Legal Approach, Benin Journal of Social Sciences, Vol 18, No 1and 2 Pp 89-100

Offiong. D.A. (1991) Witchcraft, Sorcery and Magic as social control among the Ibibios of Nigeria. Enugu: Fourth Dimension Publishers. Olaitan, L.O. (2003): The feelings and attitudes of people about death and dying on terminal illness. I.J.S.E Vol. 1, No. 5 P141-151 World Health Organization (1999) The World Health Report making a difference.

Will Act 1837, United Kingdom.

Wills Law of Bendel State of Nigeria Edict, 1976 now applicable to Edo State 
